\title{
Effects of Egg Incubation Methods on Locomotor Performances of Green Turtle (Chelonia mydas) Hatchlings
}

(Kesan Kaedah Pengeraman Telur ke atas Prestasi Pergerakan Anak Penyu Agar Chelonia mydas)

\author{
MOHD UZAIR RUSLI*, JUANITA JOSEPH, HOCK-CHARK LIEW \& ZAINUDIN BACHOK
}

\begin{abstract}
Effects of different incubation methods on crawling and swimming ability of post-emergence green sea turtle (Chelonia mydas) hatchlings at Cherating (Kuantan, Pahang) and Chagar Hutang (Pulau Redang, Terengganu) Turtle Sanctuary were analysed during nesting season in 2009. Mean crawling speed of hatchlings incubated in styrofoam box, beach hatchery and in situ were at $0.042 \pm 0.008,0.136 \pm 0.026$ and $0.143 \pm 0.045 \mathrm{~m} / \mathrm{s}$, respectively. Crawling performance of hatclings from styrofoam box can be improved by keeping them for at least $48 \mathrm{~h}$ after their emergence. For swimming performance, all types of incubation methods showed significant differences in mean power-stroke rate during their early swimming effort ranging at 93-114 strokes/min. However, no correlation was found between morphological characteristics of hatchlings and swimming performance. The results from this study may give different perspective in evaluating hatchling production, which is in terms of hatchling morphological characteristics and their locomotor performance.
\end{abstract}

Keywords: Chelonia mydas; conservation; incubation methods; locomotors performance

ABSTRAK

Kesan kaedah pengeraman ke atas prestasi merangkak dan berenang anak penyu agar (Chelonia mydas) yang baru menetas di Tempat Perlindungan Penyu Cherating (Kuantan, Pahang) dan Chagar Hutang (Pulau Redang, Terengganu) telah dianalisis pada musim bertelur tahun 2009. Purata kelajuan merangkak anak penyu yang dieram di dalam kotak polisterin, pantai tempat penetasan dan in situ adalah berbeza dengan masing-masing mencatatkan 0.042 \pm 0.008 , $0.136 \pm 0.026$ dan $0.143 \pm 0.045 \mathrm{~m} / \mathrm{s}$. Prestasi merangkak anak penyu daripada kotak polisterin boleh ditingkatkan dengan cara menyimpan mereka sekurang-kurangnya 48 jam selepas menetas. Daripada aspek prestasi renangan, semua jenis pengeraman telah menunjukkan perbezaan yang signifikan dengan julat 93-114 kuak seminit. Walau bagaimanapun, perkaitan antara ciri morfologi dengan prestasi renangannya tidak ditemui dalam kajian ini. Hasil kajian ini telah memberi satu perspektif yang berbeza kepada penilaian penghasilan anak penyu iaitu dalam bentuk ciri morfologi dan prestasi pergerakan anak penyu.

Kata kunci: Chelonia mydas; kaedah pengeraman; pemeliharaan; prestasi pergerakan

\section{INTRODUCTION}

Throughout the world, green turtle (Chelonia mydas) populations have experienced significant decline over the past 100 years, especially due to habitat degradation (alteration or destruction) among other reasons as reviewed by Lutcavage et al. (1997). Hence, green turtles are currently recognised internationally as a species of conservation concern and remained as an endangered species in the International Union for Conservation of Nature (IUCN) Red List of Threatened Animals in 2004 (Seminoff 2004). Currently, there is an active management of sea turtle rookeries throughout the world, including transferring of egg clutches into hatcheries. However, the relocation of clutches should be undertaken only if by leaving the clutches in-situ (undisturbed) will result in their destruction (Mortimer 1999).

There are two methods used to incubate sea turtle egg clutches in Malaysia, namely the in-situ and ex-situ practices. The in-situ method is the practice where the nest is marked and left undisturbed to incubate naturally after being laid by the females. Once hatched, the hatchlings from in-situ nests will crawl naturally down the beach. The ex-situ method involves the relocation of egg clutches immediately after egg laying to a safer or protected location. This method is typically applied to protect clutches from inundation by sea water if the nest is located too close to the high tide mark, or from predation either by humans or other animals. Relocated eggs will be buried in a protected beach hatchery or in styrofoam boxes. Upon emergence, hatchlings will be collected and released at a certain point on the beach.

In general, except for Redang Island, the majority of sea turtle conservation programs in Malaysia practise the ex-situ egg incubation method. Sea turtle eggs are transferred into protected beach hatcheries. In some cases, the egg clutches were incubated in styrofoam boxes. Even though incubation in styrofoam boxes were not recommended for sea turtle conservation, in certain cases, 
this method is used due to unavoidable circumstances. For instance, in 2009 the hatchery at Cherating Turtle Sanctuary was under renovation, thus styrofoam boxes had to be used. Although different methods are used to incubate eggs in hatchery management, the quality of hatchlings (in terms of locomotor performance and morphological characteristic) produced by these different methods (insitu and ex-situ) is little known and this needs further investigation. More than half a million hatchlings of green turtle have been released back to the sea annually from all the sea turtle hatcheries in Peninsular Malaysia (east and west coasts) over the last decade (Department of Fisheries, unpublished data). However, studies assessing the quality of hatchlings produced are limited. Could these hatcheries be producing poor quality hatchlings, hence resulting in relatively poor contribution of recruits to sustain a stable population of sea turtles for the future?

In order to test whether incubation methods could influence the quality of hatchlings, morphological characteristics, crawling and initial swimming performance of hatchlings were measured as an index of hatchling quality. Both of these performance measures are likely to affect the predation rate of hatchlings as they proceed down the beach towards the water line and swim to the deeper off-shore waters (Gyuris 2000). Hence, hatchlings have to be as fit as possible to give them the best chance to survive while swimming across predator rich near-shore waters.

\section{MATERIALS AND METHODS}

\section{EXPERIMENTAL DETAILS}

This study was conducted at the Turtle Sanctuaries in Cherating, Pahang and Chagar Hutang, Redang Island, Terengganu. These sites were chosen because different methods of egg incubation were used at each site. Geographically these two locations are situated along the east coast of Peninsular Malaysia and facing directly to the South China Sea. As part of the conservation program in place, all sea turtles nesting at Cherating and Chagar Hutang are double-tagged using inconel tags. This ensures the identification of each individual female that comes up to lay their eggs, making it possible to conduct this study at these sites. Morphological characteristics of newly emerged hatchlings were measured prior to the locomotor performance measurements. Two types of locomotor performances were chosen in this study: crawling and swimming performances. Only one incubation method was used on each clutch, meaning the entire clutches were assigned to one of the three incubation methods; in-situ (19 clutches) conducted at Chagar Hutang while styrofoam box ( 7 clutches) and hatchery (20 clutches) were conducted at Cherating. Nest depths were recorded during nest excavation by the ranger and incubation temperature was not measured in any of the methods. However nest depth of the styrofoam box incubated clutches were uniform at $26 \mathrm{~cm}$ limited by the height of the box (length: $45 \mathrm{~cm}$, width: $35 \mathrm{~cm}$ and height: $28 \mathrm{~cm}$ ).

\section{MEASUREMENT OF CRAWLING PERFORMANCE}

Crawling speed of hatchlings was measured on the beach at night under natural light conditions following Ischer et al. (2009). Crawling speeds were calculated from the time taken (measured with a stop watch) to transverse a $3 \mathrm{~m}$ raceway made from metal roof guttering ( $12 \mathrm{~cm}$ high and $14 \mathrm{~cm}$ wide) lined with moist beach sand (Figure 1). The raceway was placed on a seaward-facing dune and had the same slope as the dune $\left(10^{\circ}\right.$ towards the sea). The same degree of slope was used in order to make a fair comparison with a previous study by Ischer et al. (2009). Air temperature ranged between 26 and $29^{\circ} \mathrm{C}$ during these measurements. A dim light using torch light was placed at the down-hill end of the raceway and hatchlings were released into the raceway at the up-hill end. Hatchlings then crawled down the slope towards the sea as they would do under natural conditions. The ANOVA twofactor mixed model in which clutch as a random factor and incubation methods as a fixed factor was used to analyze crawling speed between groups. Since sample sizes were unequal, post hoc pair-wise Tukey test was used. Correlation was used to determine whether the crawling speed of hatchlings was significantly affected by incubation duration of egg clutches. Coefficient of variation $(\mathrm{CV})$ was used to measure the dispersion of intra-nest crawling speed. The CV values were calculated from the ratio of the standard deviation to the mean of the crawling speed values.

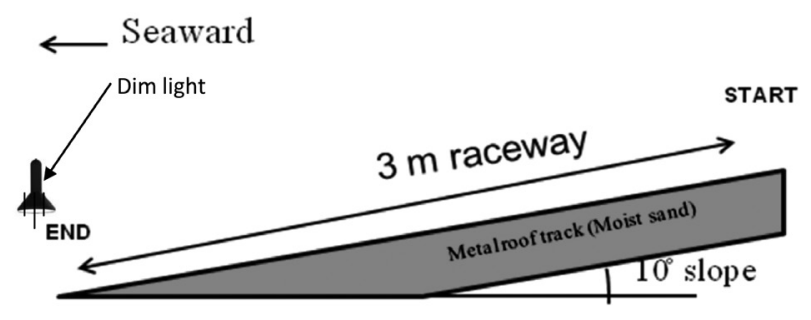

FIGURE 1. Raceway setup for crawling activity test 


\section{MEASUREMENT OF SWIMMING PERFORMANCE}

Immediately after undertaking morphological measurements, seven hatchlings were selected from each clutch in both protocols and placed individually in a glass aquarium $(60 \mathrm{~cm}$ length and $30 \mathrm{~cm}$ width) filled with $20 \mathrm{~cm}$ of seawater at $28^{\circ} \mathrm{C}$ (Figure 2). Each hatchling was fitted with a rubber-band harness which did not inhibit flipper movements. The rubber-band harness was attached via a nylon line to the retort stand above the aquarium. The tether was of a length which prevented the turtle from touching the sides or bottom of the aquarium. A low intensity light was placed at one end of the tank and the remaining sides of the tank were covered with black paper to encourage unidirectional swimming. Hatchlings were only videotaped for $10 \mathrm{~min}$, after being introduced to the tank for $30 \mathrm{~min}$ following the protocol of Wyneken and Salmon (1992). Front flippers stroke frequency during a power-stroking bout was counted at the first, fifth and ninth min of the 10 min recording period by using a hand-held counter. The results were analyzed by one-way ANOVA with powerstroke rate as the dependent variable and incubation method as the fixed factor. Correlation was used to determine whether the swimming effort of hatchlings varied with morphological characteristics of hatchlings.

\section{RESULTS}

\section{MORPHOLOGICAL CHARACTERISTICS}

Morphological measurements were made on hatchlings from 44 nests (seven styrofoam box, 20 hatchery and 17 in-situ) at Cherating and Chagar Hutang. The samples were successfully collected from more than $10 \%$ of the nesting female population. The 385 clutches of green turtle eggs laid in 2009 at Chagar Hutang, Redang Island came from just 91 different females (59 newly-tagged and 32 remigrating turtles that nested in previous years) as reported in the SEATRU Newsletter 2009. At Cherating, the smaller number of clutches tested from the styrofoam box method was due to the fact that managers only incubated 25 clutches using this method in the 2009 nesting season. A greater number of beach hatchery clutches were sampled because the emergence time of hatchlings was easy to predict, compared with those from in-situ nests.

Nearly all (93.3\%) of the styrofoam box hatchlings had residual yolk protruding outside their abdominal cavity that were not seen on hatchery and in-situ hatchlings. There were significant differences in straight carapace length, SCL (One-way ANOVA, $\mathrm{F}_{2,733}=19.342$, $p<0.05$ ) and straight carapace width (SCW) (Oneway ANOVA, $\left.\mathrm{F}_{2,733}=6.221, p<0.05\right)$ between different incubation methods (Figure 3). In details, both SCL and SCW from styrofoam box had a significant difference compared with the others (Tukey post-hoc pairwise comparison, $p<0.05)$. In contrast, only weight of hatchlings showed no significant difference (One-way ANOVA, F2, $733=2.475, p>0.05$ ) between incubation methods. The intra-nest coefficient of variation (CV) of hatchling weight ranged from 1.7 to $7.2 \%$.

\section{CRAWLING PERFORMANCE}

Incubation methods influenced the hatchling crawling speed (One-way ANOVA, $\mathrm{F}_{2,424}=244.9, p<0.05$ ). Post hoc pair-wise Tukey tests showed that hatchlings from styrofoam boxes were significantly slower at only $0.042 \pm 0.008 \mathrm{~m} / \mathrm{s}(p<0.05)$ compared with hatchlings from hatchery and in-situ clutches at $0.136 \pm 0.026$ and $0.143 \pm 0.045 \mathrm{~m} / \mathrm{s}$, respectively. However, hatchlings from in-situ and hatchery clutches showed no significant difference $(p>0.05)$ in crawling speeds. The coefficient of variation $(\mathrm{CV})$ for hatchling crawling speed were calculated for each clutch. Clutches incubated in styrofoam boxes had greater CV values (mean 48.8\%; range 26.7-68.4\%) compared with the other methods (20.3\%; range 10.4$33.8 \%$ ).

Hatchlings from styrofoam boxes were also tested for the effects of retention time prior to crawling measurement. This additional experiment was conducted to investigate

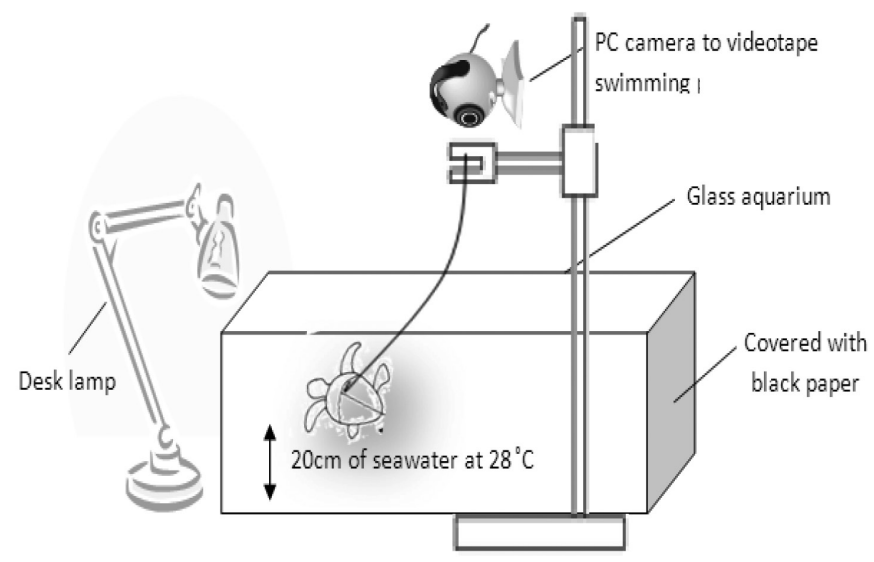

FIGURE 2. Experimental setup for swimming activity analysis 


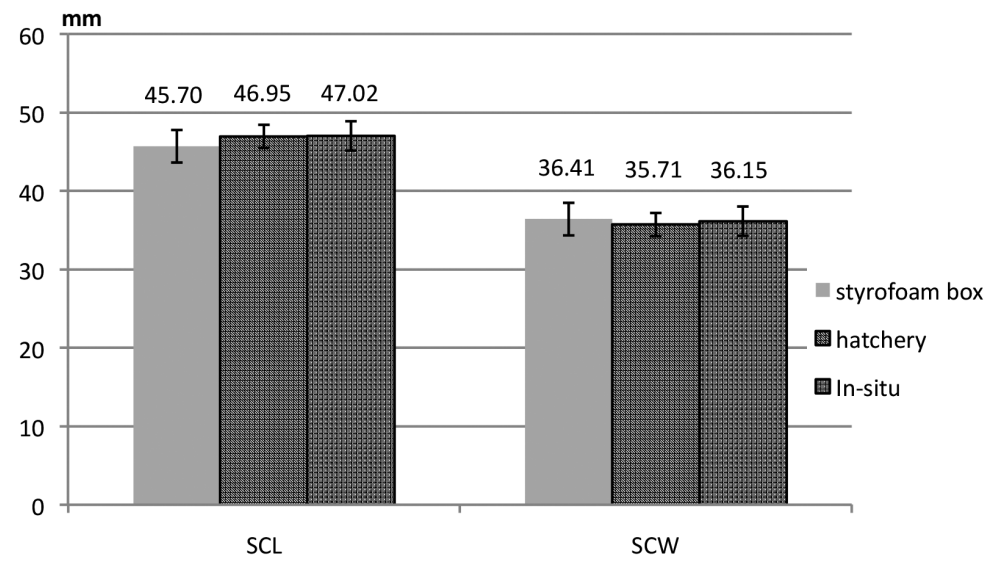

FIGURE 3. Comparison of hatchling mean size (straight carapace width, SCW and straight carapace length, SCL) hatched from three different incubation methods

if crawling performance can be improved from hatchlings produced for styrofoam box incubation. We found that the mean crawling speed showed some increment as retention time increased from 0.031 to $0.074 \mathrm{~m} / \mathrm{s}$ after being kept in the styrofoam box for $48 \mathrm{~h}$ after emergence. Moreover, there was a significant effect of retention time on hatchling crawling speed (One-way ANOVA, $\mathrm{F}_{2,72}=57.897, p<0.05$ ) with hatchlings measured $48 \mathrm{~h}$ post-hatch having faster crawling speeds than hatchlings from 0 and $24 \mathrm{~h}$ posthatch (Tukey post-hoc pairwise comparison, $p<0.05$ ). After $24 \mathrm{~h}$ of retention time, there was no significant change in hatchling crawling speed (Tukey post-hoc pairwise comparison, $p=0.256$ ).

\section{SWIMMING PERFORMANCE}

Swimming performance measurements were conducted on seven individual hatchlings from each of the 44 nests sampled. All hatchlings were observed to swim vigorously once introduced into the water tank. Only two types of swimming strokes were observed namely the power stroke and dog paddling. The result showed that incubation method does influence hatchling swimming performance (Figure 4; One-way ANOVA, $\mathrm{F}_{2,74}=6.282, p<0.05$ ). Post hoc pair-wise Tukey tests showed that hatchlings from insitu clutches had slower power stroke rates than hatchlings from hatchery clutches $(p<0.05)$. However hatchlings from styrofoam boxes had similar swimming performance as the others. In addition, the morphological characteristics were plotted against swimming stroke rate of hatchlings. However, there was no significant correlation between hatchling SCL, SCW, carapace size index and mass and power stroke rate during a power-stroking bout. Summary results from the whole experiment are shown in Table 1.

\section{DISCUSSION}

Hatchling carapace length and weight in this study were found to be similar to other green turtle hatchlings from Asian rookeries, though considerably smaller than those from the Eastern Australian rookeries (Heron Is., Raine Is. and Baramble Cay) and the French Frigate Shoals rookery in Hawaii (Table 2). These differences were probably due

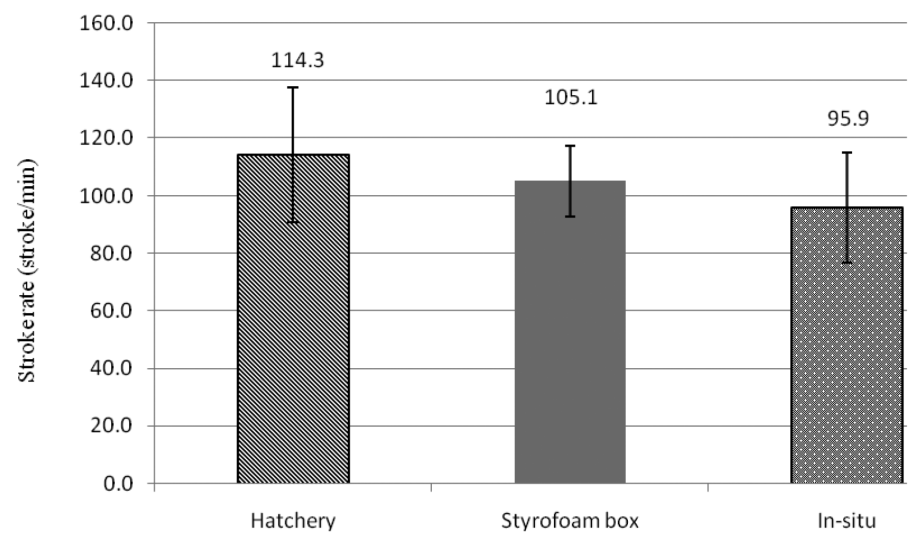

FIGURE 4. Mean power stroke rate during a power-stroking of hatchling swimming activity from three different incubation methods 
TABLE 1. Incubation period and hatchling morphological characteristics of green turtles (C.mydas) from different incubation methods

\begin{tabular}{lccc}
\hline Variable & $\begin{array}{c}\text { Styrofoam box } \\
\text { (clutch =7) }\end{array}$ & $\begin{array}{c}\text { In-situ } \\
\text { (clutch }=19)\end{array}$ & $\begin{array}{c}\text { Hatchery } \\
(\text { clutch }=20)\end{array}$ \\
\hline Incubation period (days) & $48.6 \pm 0.8$ & $51.9 \pm 3.1$ & $52.6 \pm 1.8$ \\
Hatchlings weight (g) & $21.9 \pm 1.6$ & $21.5 \pm 2.5$ & $21.7 \pm 1.5$ \\
Straight Carapace Length, SCL (mm) & $45.7 \pm 2.1$ & $47.0 \pm 1.9$ & $47.0 \pm 1.5$ \\
Straight Carapace Width, SCW (mm) & $36.4 \pm 1.9$ & $36.2 \pm 1.6$ & $35.7 \pm 1.7$ \\
Swimming speed (stroke/min) & $105.1 \pm 12.2$ & $95.9 \pm 19.1$ & $114.3 \pm 23.3$ \\
\hline
\end{tabular}

TABLE 2. Carapace lengths and body weights of green turtle hatchlings in the Pacific Ocean region

\begin{tabular}{|c|c|c|c|c|c|c|}
\hline \multirow{2}{*}{ Location } & \multicolumn{2}{|c|}{ Carapace Length (mm) } & \multicolumn{2}{|c|}{ Weight (g) } & \multirow{2}{*}{$\begin{array}{l}\text { Hatchlings } \\
(\mathrm{N})\end{array}$} & \multirow{2}{*}{ Reference } \\
\hline & Mean & Range & Mean & Range & & \\
\hline Cherating, Pahang & 46.63 & $36.42-50.27$ & 21.73 & $18.3-26.6$ & 406 & Current study \\
\hline Chagar Hutang, Redang Is. & 46.31 & $38.55-52.25$ & 20.34 & $12.9-26.7$ & 649 & Current study \\
\hline Northern Cyprus & 46.1 & $39-51$ & 19.84 & $13-26$ & 673 & Ozdemir \& Turk (2005) \\
\hline Orchid Is., Taiwan & 46.5 & $43.9-47.7$ & 22.1 & $17.5-27.4$ & 1239 & Cheng et al. (2009) \\
\hline Wan-An Is., Taiwan & 46.9 & $41.4-52.4$ & 22.7 & $16.5-32$ & 327 & Chen \& Cheng (1995) \\
\hline Heron Is., East Australia & 49.7 & $40.2-51.9$ & 24.8 & $19.8-28.4$ & 110 & Limpus (1980) \\
\hline Heron Is., East Australia & 48.9 & $45.5-53.5$ & 24.93 & $19.0-30.5$ & 220 & Limpus et al. (1984) \\
\hline Raine Is., East Australia & 48.6 & $38.4-54.3$ & 23.8 & $17.5-29.5$ & 694 & Limpus et al. (2003) \\
\hline Bramble Cay, East Australia & 48.5 & $39.3-53.5$ & 23.2 & $14.5-29.0$ & 2248 & Parmenter (1978) \\
\hline Ashmore, Weast Australia & 46.8 & $44.1-49.1$ & 20.4 & $17.0-22.5$ & 21 & Guinea (1995) \\
\hline French Frigate Shoals, Hawaii & 53 & $48-59$ & 31.0 & $25.0-35.0$ & 556 & Balazs (1980) \\
\hline Galapagos Is. & 46.2 & $41.0-49.5$ & - & - & 29 & Pritchard (1971) \\
\hline French Frigate Shoals, Hawaii & - & - & 31.0 & $25-35$ & 120 & Balazs (1980) \\
\hline
\end{tabular}

to the fact that they are from different genetic stocks. The difference in morphological characteristics within the same species from various genetic stocks has been established. For instance, Moritz et al. (2002) have demonstrated that the Western Australian stock (Ashmore reef) have smaller hatchlings size compared with the Eastern Australian stock. In this study, hatchlings from Cherating and Chagar Hutang rookeries come from the same genetic stock (Joseph 2006) which suggest that the differences in hatchling size could have been influenced by the different incubation methods. The results from crawling performance measurement showed that only styrofoam box incubation affected the crawling speed of hatchlings. Although relocation of egg clutches is a common hatchery practice, it did not affect crawling speed of hatchlings as hatchery hatchlings showed no significant difference with in-situ performance. Another possible reason is that styrofoam boxes generally had shallower nest depth compared with nest incubated in the hatchery because of their limited size. As the nest depth is also vital to get optimal temperature throughout the incubation period it would also affect the duration of incubation and time of hatchling emergence as demonstrated by Hamann et al. (2002). The authors further described that several days were needed upon hatching in the nest to increase their locomotor ability while digging upwards. Based on this study, the shallow nest depth in styrofoam boxes most likely affected the hatchling crawling performance.
According to Hamann et al. (2002), the upward digging by the hatchlings while in the sand is a process that typically takes 2-3 days for green turtles. Upward digging is a periodic activity which alternates with long periods of sleep or rest before the hatchlings finally emerges from the sand (Godfrey \& Mrosovsky 1997). The time spent will allow hatchlings to absorb their external yolk into their abdominal cavity (Godfrey \& Mrosovsky 1997; Hamann et al.2007). The size of the mother could influence the clutch size, depth and location of the nest (Carr \& Hirth 1961). If so, then hatchlings in deeper nests would most likely take a longer time to reach the nest surface. The shorter distance to the surface found in the styrofoam box experiments did not provide enough time for the hatchlings to absorb their residual yolk. This explains why hatchlings incubated in hatchery and in-situ nests have their yolk absorbed into the abdominal cavity and were extremely active once they emerged from their nests.

Further investigations conducted on the development of hatchlings in the styrofoam boxes showed that an improvement in mean crawling speed can be seen after retention for $48 \mathrm{~h}$ before release. Although there was some increment of mean crawling speed after $24 \mathrm{~h}$ retention, the difference was not significant from the newly hatched group. However, the increment after $48 \mathrm{~h}$ retention was only $0.074 \mathrm{~m} / \mathrm{s}$ which was approximately half of the newly emerged in-situ $(0.143 \mathrm{~m} / \mathrm{s})$ and hatchery $(0.136$ 
$\mathrm{m} / \mathrm{s}$ ) crawling performance values. Hence, crawling performance of hatchlings from styrofoam boxes was still very poor compared with the other methods even though they were kept for two days in the box after emergence. In order to enhance their locomotor performance, this study recommends that hatchlings incubated in styrofoam boxes should be kept for at least $48 \mathrm{~h}$ prior to their release onto the beach or the height of the boxes increased to simulate the depth of a natural nest.

It is important to recognize that the guidelines of hatchery management by Mortimer (1999) has suggested that hatchlings should not be kept in water prior to release. Even the newly emerged hatchlings from styrofoam box incubators, that were characterized as slow and unfit, will engage in a 'swim frenzy' behavior once introduced into the water. It is feared that hatchlings would exhaust their energy reserves stored in their yolk before their actual swimming effort out to sea.

Within a nest, all hatchlings measured came from the same cohort (first cohort of emergence) and would have similar body temperature, yet there was considerable variation in crawling speed between hatchlings. Biological data such as morphological characteristics, performance, growth typically have CV ranging between 10 and $15 \%$ (Balaam 1972), but higher variability in performance traits such as crawling speed is more typical in ectotherms (Ischer et al. 2009). This indicates that in one particular cohort of emergence, crawling performance of hatchlings is not uniform in relation to each other. It is commonly assumed that predation rate of hatchlings by terrestrial predators is directly related to the period of time hatchlings spend crawling down the beach. Thus in areas where terrestrial predators are abundant, strong selection is expected for fast crawling hatchlings. However, in the current study and that of Ischer et al. (2009), large inter-individual variation in crawling performance in hatchlings from the same nest and cohort was found.

Green turtle hatchlings typically emerged en-masse from nests in batches of 50-100 and then scramble down the beach simultaneously. Dehn (1990) has proposed that mass emergence is a 'swamping strategy' which has the effect of increasing the overall chances of a hatchling's survival. The author further explained that predators can only eat a limited number of hatchlings at one sitting. As discussed by Ischer et al. (2009), ghost crabs can only handle one hatchling at a time and by the time it has finished with it the rest of the cohort would have successfully reached the water line. This may explain the wide inter-individual variation in crawling speed within a nest. However, hatchlings produced from styrofoam boxes are of considerable concern because they have both a relatively greater CV (48.8\% vs. $20.3 \%)$ and slower crawling speed ( $0.04 \mathrm{vs} .0 .15 \mathrm{~m} / \mathrm{s})$ than hatchlings from eggs incubated in-situ and beach hatcheries. These differences are probably due to the relatively immature state of emerging hatchlings in the styrofoam box method as their egg yolk were still protruding outside their body. Thus, this type of hatchlings will most probably face higher predation rates while crawling down the beach.
Green turtle hatchlings are characterized by vigorous swimming 'frenzy' powered by powerful strokes of the front flippers immediately after entering the water and this behavior can last up to $24 \mathrm{~h}$ (Wyneken \& Salmon 1992). Throughout this phase, power-stroking bouts last 5-10 s and typically are separated by 2-5 s of dog paddling when they also lift their head out of the water to take a breath of air. The current study showed that most hatchlings swam vigorously immediately after being introduced into the tank, but there were some hatchlings spent their first few min resting on the surface before vigorous swimming began. This abnormal activity may only occur in experimental conditions because of the absence of stimulation by waves that are usually present when leaving natural beaches (Chung et al. 2009). It is known that hatchlings use wave direction as one of the cues to start their early swimming (Goff et al. 1998). Moreover, before the swimming trials began, the hatchlings were disturbed while moving them from the beach to the laboratory and while taking morphological measurements. Therefore, under natural conditions, power-stroke rate might be slightly greater than was recorded in this study.

This study showed that swimming performance of green turtle hatchlings from the Cherating and Chagar Hutang rookeries was influenced by incubation methods. The power-stroke rate of beach hatchery incubated hatchlings was greater than hatchlings from in-situ incubated eggs. One possible explanation for this difference is that the eggs used in this experiment came from different locations. The beach hatchery method was conducted at Cherating while the in-situ method experiments were done at Chagar Hutang. Even though females nesting at these rookeries come from the same genetic stock within the east coast of Peninsular Malaysia (Joseph 2006), the hatchlings might be using different swimming strategies to avoid predators in the shallow waters surrounding the nesting beach during early swimming. Wyneken et al. (2008) has demonstrated the differences in swimming activity exhibited by hatchling loggerhead sea turtles (Caretta caretta) from different nesting populations in South Florida even though they are from the same genetic stock. Further investigation should be done at Chagar Hutang and Cherating in order to explain the difference in swimming performance of hatchlings from these rookeries. From personal observations, the Chagar Hutang rookery faces a coral reef area in the Redang Island Marine Park, while the Cherating rookery is fronted by a slightly muddy beach and is unlikely to have the same population structure of fish and other potential predators. Therefore, further studies are needed with these ecological differences or associated adaptations to the swimming behaviour of green turtle hatchlings.

\section{ACKNOWLEDGEMENTS}

Special thanks to all rangers at the Chagar Hutang and Cherating Turtle Sanctuaries for assisting in the field studies. The financial support was provided by SEATRUINOS Turtle Fund of Universiti Malaysia Terengganu. We thank Dr. David T. Booth (The University of Queensland) 
for reviewing an early draft of this manuscript. This study was conducted under a permit issued by the Turtle and Marine Ecosystem Centre (TUMEC), Department of Fisheries.

\section{REFERENCES}

Balaam, L.N. 1972. Fundamental of biometry. Science of Biology Series. London: George Allen and Unwin Ltd.

Balazs, G.H. 1980. Synopsis of biological data on the green turtle in the Hawaii Islands. NOAA Technical Memorandum NMFS, Honolulu, Hawaii.

Carr, A. \& Hirth, H. 1961. Social facilitation in green turtle siblings. Animal Behaviour 9(1-2): 68-70.

Chen, T.H. \& Cheng, I. 1995. The breeding biology of the green turtle, Chelonia mydas (Reptilia: Cheloniidae) at Wan-An Island, Peng-Hu Archipelago, Taiwan. I. Nesting ecology. Marine Biology 124: 9-15.

Cheng, I.J., Huang, C.T., Hung, P.Y., Ke, B.Z., Kuo, C.W. \& Fong, C.L. 2009. Ten years of monitoring the nesting ecology of the green turtle, Chelonia mydas, on Lanyu (Orchid Island), Taiwan. Zoological Studies 48(1): 83-94.

Chung, F.C., Pilcher, N.J., Salmon, M. \& Wyneken, J. 2009. Offshore migratory activity of hawksbill turtle (Eretmochelys imbricata) hatchlings, II. Swimming gaits, swimming speed, and morphological comparisons. Chelonian Conservation and Biology 8(1): 35-42.

Dehn, M. 1990. Vigilance for predators: Detection and dilution effects. Behavioral Ecology and Sociobiology 26: 337-342.

Godfrey, M.H. \& Mrosovsky, N. 1997. Estimating the time between hatching of sea turtle and their emergence from the nest. Chelonian Research Foundation 2(4): 581-585.

Goff, M., Salmon, M. \& Lohmann, K. 1998. Hatchling sea turtles use surface waves to establish a magnetic compass direction. Animal Behaviour 55(1): 69-77.

Guinea, M.L. 1995. Report to Australian Nature Conservation Agency: The sea turtles and sea snakes of Ashmore Reef National Nature Reserve. School of Biological Sciences, Northern Territory University, Darwin (unpublished)

Gyuris, E. 2000. The relationship between body size and predation rates on hatchlings of the green turtle (Chelonia mydas): Is bigger better. In Sea Turtles of the Indo-Pacific: Research Management and Conservation, edited by Pilcher, N.J. \& Ismail, G. Devon, UK: Asean Academic Press. pp. 143-147.

Hamann, M., Jessop, T.S. \& Schäuble, C.S. 2007. Fuel use and corticosterone dynamics in hatchling green sea turtles (Chelonia mydas) during natal dispersal. Journal of Experimental Marine Biology and Ecology 353(1): 13-21.

Hamann, M., Jessop, T., Limpus, C. \& Whittier, J. 2002. Aspects of the emergence and dispersal physiology in hatchling green sea turtles from Heron Island, Australia. 20th Annual Symposium on Sea Turtle Biology and Conservation, National Marine Fisheries Service.

Ischer, T., Ireland, K. \& Booth, D.T. 2009. Locomotion performance of green turtle hatchlings from the Heron Island Rookery, Great Barrier Reef. Marine Biology 156(7): 1399-1409.

Joseph, J. 2006. Conservation genetics of green (Chelonia mydas) and hawksbill (Eretmochelys imbricata) sea turtles of Southeast Asia. PhD Thesis. University of London, London (unpublished).
Limpus, C.J. 1980. The green turtle in eastern Australia. In Management of Turtle Resources, Research Monograph 1, Townville: James Cook University of Queensland.

Limpus, C.J., Miller, J.D., Parmenter, C.J. \& Limpus, D.J. 2003. The green turtle, Chelonia mydas, population of Raine Island and the northern Great Barrier Reef: 1843-2001. Memoirs Queensland Museum 49(1): 349-440.

Limpus, C.J., Fleay, A. \& Guinea, M. 1984. Sea turtles of the Capricornia Section, Great Barrier Reef. In The Capricornia Section of the Great Barrier Reef: Past, Present and Future, edited by Ward, W.T. \& Saenger, P.P. Brisbane: Royal Society of Queensland and Australian Coral Reef Society.

Lutcavage, M.E., Plotkin, P. \& Peter, L. 1997. Human impacts on sea turtle survival. In The Biology of Sea Turtles, edited by Lutz, P.L. \& Musick, J. Boca Raton: CRC Press. pp.387-409.

Moritz, C., Broderick, D., Dethmers, K., Fitz Simmons, N. \& Limpus, C.J. 2002. Population genetics of Southeast Asian and Western Pacific green turtles, Chelonia mydas. Final Report to UNEP/CMS. 20th June.

Mortimer, J.A. 1999. Reducing threats to eggs and hatchlings. Hatcheries. In Research and Management Techniques for the Conservation of Sea Turtles, edited by Eckert, K.L., Bjorndal, K.A., Abreu-Grobois, F.A. \& Donnelly, M. Washington, DC: IUCN/SSC Marine Turtle Specialist Group Publication No. 4. pp. $175-178$.

Ozdemir, B. \& Turkozan, O. 2005. Carapacial scute variation in green turtle, Chelonia mydas hatchlings in northern Cyprus. Turkish Journal of Zoology 30: 141-146.

Parmenter, C.J. 1978. Resume of Bramble Cay - results 1977/78 season. Unpublished report to Applied Ecology Pty. Ltd. (Australian National Parks and Wildlife Service, Canberra.)

Pritchard, P.C.H. 1971. Galapagos sea turtle - preliminary findings. Journal of Herpetology 5(1-2): 1-9.

Seminoff, J.A. 2004. Chelonia mydas. In IUCN 2014. IUCN Red List of Threatened Species. Version 2014.1. <www. iucnredlist.org $>$. Accessed on 15 June 2014.

Wyneken, J., Madrak, S.V., Salmon, M. \& Foote, J. 2008. Migratory activity by hatchling loggerhead sea turtles (Caretta caretta L.): Evidence for divergence between nesting groups. Marine Biology 156(2): 171-178.

Wyneken, J. \& Salmon, M. 1992. Frenzy and postfrenzy swimming activity in loggerhead, green, and leatherback hatchling sea turtles. Copeia 2: 478-484.

Mohd Uzair Rusli*, Hock-Chark Liew \& Zainudin Bachok School of Marine Sciences and Environment

Universiti Malaysia Terengganu

21030 Kuala Terengganu, Terengganu

Malaysia

Juanita Joseph

Institute of Oceanography and Environment

Universiti Malaysia Terengganu

21030 Kuala Terengganu, Terengganu

Malaysia

*Corresponding author; email: uzair@umt.edu.my

Received: 12 June 2013

Accepted: 30 June 2014 